\title{
授業形式の違しが学習意欲に及ぼす効果につして 一学習意欲を高める授業形式の検討一
}

\author{
Effects of Lesson Form on Willingness to Learn: \\ A Study of Lesson Form to Raise Willingness to Learn
}

\section{吉澤 隆志1）＼cjkstart藤沢 しげ子2)}

TAKASHI YOSHIZAWA, RPT, MS ${ }^{1)}$, SHIGEKo FUJISAWA, RPT, PhD²)

1) Department of Physical Therapy, Yachiyo Rehabilitation College: 11-1-30 Yachiyodaikita, Yachiyo City, Chiba 276-0031, Japan.TEL +81 47-481-7320 FAX+8147-481-7321 E-mail t.yoshizawa@yachiyo-reha.jp

2) Department of Physical Therapy, Faculty of Science, International University of Health and Welfare

Rigakuryoho Kagaku 24(1): 35-39, 2009. Submitted Jul. 14, 2008. Accepted Aug. 8, 2008.

\footnotetext{
ABSTRACT: [Purpose] We compared lesson consciousness between self-learning and traditional teaching classes and investigated the correlation with willingness to learn. [Subjects] The subjects were 116 students attending a physical therapy vocational school. [Methods] We conducted self-learning and traditional teaching classes and compared them by performing factor analysis on the results of a lesson consciousness questionnaire; we also sought correlation with the results of a willingness to learn questionnaire. [Results] In the results of the factor analysis of the self-learning class, the subscale scores of Factor 1 (self-originating approach to learning) as well as Factor 3 (exchanges with classmates) were higher than those of the traditional teaching class. Moreover, we found that Factor 1 was mainly based on self-motivation, and that Factor 3 was correlated with suitability for college. [Conclusion] We consider self-learning classes are a form of teaching which can raise levels of self-motivation and suitability for college.

Key words: self-learning classes, traditional teaching classes, willingnes to learn

要旨：〔目的〕自己学習授業と従来授業における授業意識の比較と, 学習意欲との相関を検討した。〔対象〕某A専 門学校理学療法学科学生 (116名) とした。〔方法〕自己学習授業と従来授業とを実施し, 授業意識アンケート結果 について因子分析を行い, 両者を比較した。また, 学習意欲アンケート結果との相関を調べた。〔結果〕自己学習 授業における因子分析結果のうち第 1 因子（自ら授業に取り組む姿勢）および第 3 因子（クラスメイトとの交流） は, 従来授業よりも下位尺度得点が高かった。また, 第 1 因子は主に内発的動機づけ, 第 3 因子は学院への適応度 との相関が見られた。〔結語〕自己学習授業は, 内発的動機づけや学院への適応度を高めることの出来る授業形式 であると考えられた。 キーワード : 自己学習授業, 従来授業, 学習意欲

1)八千代リハビリテーション学院 理学療法学科 : 千葉県八千代市八千代台北11-1-30（テ276-0031）

TEL 047-481-7320 FAX 047-481-7321

2) 国際医療福祉大学 保健医療学部理学療法学科

受付日 2008年7月14日＼cjkstart受理日２008年8月8日
} 


\section{I. はじめに}

近年, 学生の学習意欲の低下が指摘されている。そ の原因のひとつに, 知識偏重主義が挙げられている ${ }^{1,2)}$ そのため, 学生の学習意欲を持続・向上させる授業方 法の開発は, 重要な課題と考えられている1)。その一つ の試みとして, 課題解決能力や自己教育力を育てる授 業があると報告されている ${ }^{3-5)}$ 。具体的には, ある課題 について, 学生自らが文献等を使い積極的に調べる授 業形式（以下，自己学習授業）である3)。しかし，実際 に自己学習授業の効果について, 教員が板書し学生が ノートをとる形式 (以下, 従来授業) との比較検討を 行った研究はほとんどない。そこで, 今回, 科目毎に 自己学習授業之従来授業とを実施し, その後, 両者の 授業に関するアンケートを行い若干の知見を得たので, ここに報告する。

\section{II. 対象と方法}

対象は, 某 $\mathrm{A}$ 専門学校理学療法学科昼間コース 2 年生 および夜間コース 3 年生, 合計 116 名 “男性 80 名・女性 36 名, 平均年齢 $24.6 \pm 5.6$ 歳” (以下, 学生) とした。こ こで, 学生に対して, 研究趣旨・アンケート内容・ア ンケート記載内容が成績と関係ない旨, 結果の処理方
法, 研究結果発表の場について十分な説明を行った後 にアンケート記入を記名にて行うと共に, 同意書に署 名をした者についてのみ研究対象とした。なお，本研 究における倫理的配慮については, 理学療法科学学会 研究倫理委員会より承認を得た。

平成 19 年度後期において, 同一教員が異なる科目を 自己学習授業と従来授業という異なる形式にて行った。 具体的に, 自己学習授業は “神経難病のPT”, 従来授業 は“義肢装具学II”の科目にて実施した。両者の授業内 容は異なるが，どちらも専門科目である。ここで，自 己学習授業の実施方法としては, 基本的に 2 回の授業 を1クールとした。1回目の授業において疾患について の概略の説明を行い, 次いで学生に調べて欲しい項目 や内容を伝えた。1 週間後の 2 回目の授業は, 学生の質 問を受けると共に他の時間は自ら文献を調べまとめる 作業に費やした。その後, 各学生がレポートを教員に 提出し, チェック後に優秀者の発表と共に返却すると いう流れを繰り返した。ここで，授業当初における注 意点として，授業の目的や評価方法について十分に伝 えるようにした6)。また，後期授業の最後に授業に関す るアンケートを実施した。

授業アンケートは，2 種類実施した。1つ目は，学生 の授業に取り組む意識に関しての内容である（表 1）。 また, 授業意識アンケートは 20 項目 5 件法にて行い, 自

表1 授業比較アンケート

(1) 少しでも良い評定をもらうために勉強した。

(2) 授業に意欲的に取り組むことが出来た。

(3) 授業のことについて，友達と話寸機会が多かった。

(4) 授業で自分が何を学ぶべきかを意識して取り組んだ。

(5) 自ら積極的に，授業内容をまとめる作業を行った。

(6) 友達と積極的に, 授業内容の情報交換を行った。

(7) 他の学生に負けないために努力した。

(8) 自ら積極的に授業に参加した。

(9) 最終的に良い点数を獲得するために努力した。

(10) 授業の話をするために, 自ら積極的に友達に話しかけた。

(11) 適切な資料・文献を探寸方法を知ることが出来た。

(12) 将来, 役に立つと思う内容については, 自ら積極的に学習した。

(13) 学問的内容のまとめ方について, 学ぶことが出来た。

(14) 授業の内容で分からないことがあった場合は，尋刘たり分かるまで調べた。

(15) 授業に関連のある本や資料を積極的に調べた。

(16) 今まで，あまり交流が無かったクラスメイトと話をすることがあった。

(17) この授業形式によって, 多くの知識を得ることが出来た。

(18) 単位を落とすことの無いように勉強を行った。

(19) なるべく一人で勉強するようにしていた。

(20) この授業形式は興味深く, 学習を動機付けるものであった。 
己学習授業および従来授業の両者について記載しても らった。2つ目は, 学生の学習意欲に関するアンケート である。当該アンケートの内容としては, 筆者らが行っ た研究7)において学習意欲と規定した5 項目 (内発的動 機づけ・外発的動機づけ・精神的健康度・対人関係ス キル・学院への適応度）に関するものである。南 ${ }^{8)}$ は, 「学生による授業評価はかなり高い信頼性をもつと同時 に，妥当性という点においてもそれを支持する結果が えられた。と述べている。

まず，自己学習授業におけるアンケート結果につい て, 因子分析（主因子法・バリマックス回転）を行っ た。次に，因子分析によって抽出された因子について， 自己学習授業および従来授業の両者における下位尺度 得点 (項目平均值) を算出し, Mann-Whitney の $U$ 検定 を用いて比較した。最後に, 自己学習授業における下 位尺度得点と, 学習意欲アンケート結果について, ス ピアマンの相関係数を用いて関係を調べた。なお，統
計解析には, spss14.0j for Windows（エス・ピー・エス・ エス株式会社）を用いた。

\section{III. 結 果}

自己学習授業におけるアンケート結果の因子分析の 結果,「自ら授業に取り組む姿勢（以下，第 1 因子）」「高 い評定（以下，第2因子)」「クラスメイトとの交流（以 下, 第 3 因子)」という因子が抽出された（表2）。また, 自己学習授業における下位尺度得点は第 1 因子 $3.5 \pm 0.7$ 点, 第 2 因子 $3.4 \pm 0.9$ 点, 第 3 因子 $3.2 \pm 0.8$ 点, 従来授 業における下位尺度得点は第 1 因子 $3.2 \pm 0.7$ 点, 第 2 因 子 $3.2 \pm 0.8$ 点, 第 3 因子 $2.6 \pm 0.7$ 点であった。ここで, 自己学習授業と従来授業における下位尺度得点の関係 としては, 第 1 因子および第 3 因子について有意差がみ られた（表3）。最後に, 自己学習授業における下位尺 度得点と学習意欲との関係としては, 第 1 因子と内発

表2 自己学習授業アンケートにおける因子分析結果

\begin{tabular}{|c|c|c|c|c|}
\hline \multicolumn{2}{|l|}{ 項目 } & 第 1 因子 & 第 2 因子 & 第 3 因子 \\
\hline \multicolumn{5}{|c|}{ 第 1 因子：自ら授業に取り組む姿勢 $(\alpha=.90)$} \\
\hline (4) & 授業で自分が何を学ぶべきかを意識して取り組んだ。 & .80 & .05 & .13 \\
\hline (2) & 授業に意欲的に取り組むことが出来た。 & .79 & .22 & .05 \\
\hline$(12)$ & 将来，役に立つと思う内容については，自ら積極的に学習した。 & .79 & .16 & -.16 \\
\hline$(17)$ & この授業形式によって，多くの知識を得ることが出来た。 & .76 & .07 & -.03 \\
\hline$(20)$ & この授業形式は興味深く, 学習を動機付けるものであった。 & .72 & .07 & -.18 \\
\hline$(8)$ & 自ら積極的に授業に参加した。 & .66 & .25 & .07 \\
\hline$(5)$ & 自ら積極的に，授業内容をまとめる作業を行った。 & .63 & .08 & .03 \\
\hline (14) & 授業の内容で分からないことがあった場合は，尋ねたり分かるまで調べた。 & .63 & .27 & .24 \\
\hline$(11)$ & 適切な資料・文献を探す方法を知ることが出来た。 & .56 & .14 & .30 \\
\hline (13) & 学問的内容のまとめ方について，学ぶことが出来た。 & .56 & .11 & .26 \\
\hline$(15)$ & 授業に関連のある本や資料を積極的に調べた。 & .53 & .09 & .08 \\
\hline \multicolumn{5}{|c|}{ 第 2 因子 : 高い評定 $(\alpha=.78)$} \\
\hline (1) & 少しでも良い評定をもらうために勉強した。 & .17 & .92 & .01 \\
\hline (9) & 最終的に良い点数を獲得するために努力した。 & .31 & .81 & .10 \\
\hline (7) & 他の学生に負けないために努力した。 & .24 & .56 & -.14 \\
\hline (18) & 単位を落とすことの無いように勉強を行った。 & -.03 & .42 & .20 \\
\hline \multicolumn{5}{|c|}{ 第 3 因子 : クラスメイトとの交流 $(\alpha=.63)$} \\
\hline & 友達と積極的に，授業内容の情報交換を行った。 & .08 & .09 & .79 \\
\hline & 授業のことについて，友達と話す機会が多かった。 & .23 & -.01 & .71 \\
\hline (19) & なるべく一人で勉強するようにしていた。 & .26 & .10 & -.59 \\
\hline \multicolumn{2}{|r|}{ （10）授業の話をするために，自ら積極的に友達に話しかけた。 } & .20 & .28 & .57 \\
\hline & 因子寄与 & 5.45 & 2.35 & 2.18 \\
\hline & 因子寄与率 & $28.67 \%$ & $12.35 \%$ & $11.47 \%$ \\
\hline & 累積寄与率 & $28.67 \%$ & $41.02 \%$ & $52.49 \%$ \\
\hline
\end{tabular}


表3 自己学習授業と従来授業における下位尺度得点

下位尺度得点

（範囲：1-5 点）

\section{第 1 因子}

「自ら授業に取り組む姿勢」

自己学習授業

従来授業

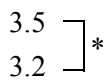

第 2 因子

「高い評定」

自己学習授業 3.4

従来授業

3.2

第 3 因子

「クラスメイトとの交流」

$\left.\begin{array}{ll}\text { 自己学習授業 } & 3.2 \\ \text { 従来授業 } & 2.6\end{array}\right]$ *

$* \mathrm{p}<0.01$

的動機づけにおいて中程度の相関および精神的健康度・ 対人関係スキル・学院への適応度において弱い相関, 第 3 因子と学院への適応度において弱い相関が見られ た（表4）。

\section{IV. 考 察}

本研究の目的は, 科目毎に自己学習授業と従来授業 とを実施し, 両者における意識授業アンケート結果の 比較と学習意欲との相関の検討である。結果としては, 自己学習授業における因子分析結果のうち第 1 因子お よび第3因子は, 従来授業よりも下位尺度得点が高かっ た。また, 第 1 因子は主に内発的動機づけ, 第3 因子は 学院への適応度との相関が見られた。ここで, 内発的 動機づけとは, 学ぶこと自体が楽しいと思えているか, 自ら積極的に学習に臨んでいるかというものである。 また, 学院への適応度とは, クラスメイトと良好な友 人関係が築けているか, 在籍している学院に満足して
いるかというものである。

教員が全てを教える授業においては，どうしても学 生は受け身となってしまう可能性がある。その場合, “学生が主体的に学び習得する”という, 本来ある心゙き 姿勢の確立が難しくなってしまう。逆に，自己学習授 業においては，学生自身が積極的に文献を調べまとめ る。その過程において, 疾患の原因や評価方法および 治療内容について疑問を持ち, 自ら解答を見つける心゙ く努力を重衫る。そのことが, 第1因子と内発的動機づ けとの間に相関が見られた理由であると考えられた。 藤本 ${ }^{9)}$ は，授業設計の鍵について「学生に答えを発見 させることである。さもなければ少なくとも予測させ よ。その結果, 自らの宣言が正しいのか否かを真剣に 吟味する気になると, その過程で積極的な学習行為が 発生するのである。」と述べている。他に, 星野ら ${ }^{10)}$ は, 「学生の努力が授業満足度を通して理解度を高める要因 となる。」と述べている。よって, 自己学習授業は内発 的動機づけを高め, 学生の積極的な学習を促すことを 可能に寸る。

また，今回の自己学習授業においては，文献を読ん でレポートにまとめる作業は自ら行うが，クラスメイ 卜間での資料や情報の交換は積極的に推奨した。その 理由は，授業により他者との関わりが増加すれば，友 人関係の交流増進や拡大に繋がると考えたからである。 実際に学生を見ていると, 調べる全ての項目について 一人で調べることは困難を要し, クラスメイトとの情 報交換が頻繁に行われていたようである。また，毎回 のレポート優秀者や教員のところには多くの学生がど のような文献を用いれば良いかを尋礼に来ていた。そ れらのことが，第 3 因子と学院への適応度との間に相 関が見られた理由であると考えた。大久保 ${ }^{11}$ は, 「友人 関係や教師との関係や学業はどの学校においても等し く価值が置かれ，学校適応に対して正の影響を与えて いると言える」と述べている。更に, 学院への適応度

表4 自己学習授業における下位尺度得点と学習意欲との相関（スピアマン）

\begin{tabular}{|c|c|c|c|c|c|}
\hline & 内発的動機づけ & 外発的動機づけ & 精神的健康度 & 対人関係スキル & 学院への適応度 \\
\hline 第 1 因子 & & & & & \\
\hline $\begin{array}{l}\text { 「自ら授業に取り組む姿勢」 } \\
\text { 第 } 2 \text { 因子 }\end{array}$ & $.59 *$ & .13 & $.29 *$ & $.30 *$ & $.26^{*}$ \\
\hline $\begin{array}{l}\text { 「高い評定」 } \\
\text { 第 } 3 \text { 因子 }\end{array}$ & $.31 *$ & $.29 *$ & .12 & .14 & $.30 *$ \\
\hline 「クラスメイトとの交流」 & .03 & -.08 & -.03 & .07 & $.34^{*}$ \\
\hline
\end{tabular}

$* \mathrm{p}<.01$ 
は筆者らの研究において定期試験成績に好影響を及ぼ すと考えられ7), 自己学習授業は友人交流の促進を行 えると共に学業成績向上の点からも適した授業形式で あるといえる。

しかしながら，全ての科目において自己学習授業が 適しているとは考えにくい。自己学習授業を行うため には，学生に基礎的知識があると共に教員が何をどの ように調べまとめればよいのかということを明確に伝 える必要がある。そうでなければ, 学生に対し十分な 効果をもたらすような自己学習授業を行うことはでき ない。また, 今回の自己学習授業を実施しての反省点 として，学生への負担が大きくなってしまったことが 挙げられる。時期的に実習直前の学生に対し自己学習 授業を行ったことに加え, ほぼ完全に, 全ての項目に ついて学生にまとめさせた。しかし, 他の教員の科目 において多数のレポートが出ていたり実習に向けての 準備がある中での自己学習授業の導入は, 負担増大の 面から慎重に考慮した方が良いと考える。従って, 今 後は時期的なことに加えて，特に重要な点のみをまと めるといった配慮を行いつつ自己学習授業を実施して いきたいと考える。

\section{引用文献}

1) 川上 博, 竹原 律, 鹿内信善 : 学ぶ意欲を持続させる授
業：Bloomらの「分析」操作を用いた授業設計．年報いわみ ざわ, 1993, 14: 15-24.

2) 北尾倫彦: 自己教育力を育てる先生. 図書文化社, 東京, 1986, pp142-148.

3) 渡辺勇一: 学生の勉学意欲を維持する授業の工夫. 新潟大学 教育研究年報, 2000, 5: 117-121。

4) 佐藤俊樹 : 自ら学ぶ意欲を育てる中学地理の課題レポート: 1年目の中間報告. 名古屋大学教育学部附属中高等学校紀要, 1997, 42: 171-176.

5) DeBourgh GA: Predictors of student satisfaction in distance-delivered graduate nursing courses: what matters most? J Prof Nurs, 2003, 19(3): 149-163.

6) 尾澤重知, 望月俊男, 江木啓訓・他 : 学習者構成型授業にお ける教授法と学習環境デザイン実験研究の評価. 日本教育工 学雑誌, 2004, 27: 73-76.

7) 吉澤隆志，太田信夫，藤沢しげ子：学習意欲が定期試験成績 に及ぼす効果. 理学療法科学, 2008, 23(2): 249-253.

8) 南 学: 学生による授業評価の信頼性と妥当性に関する検 討. 松山大学論集, 2003, 14(6): 55-67.

9) 藤本敏弘 : 学生の授業満足度を高める授業設計と授業評価の 事例 :「情報の科学」の場合. 実践女子短期大学紀要, 2006, 27: 157-171.

10) 星野敦子, 牟田博光 : 大学生による授業評価にみる受講者の 満足度に影響を及ぼす諸要因。日本教育工学雑誌，2004, 27 : 213-216.

11) 大久保智生 : 青年の学校への適応感とその規定要因 : 青年用 適応感尺度の作成と学校別の検討. 教育心理学研究, 2005, 53(3), 307-319. 